\title{
Identifikasi Nilai Agama Islam pada Anak Usia Dini
}

\author{
Bina Fitriah Ardiansari ${ }^{\bowtie}$, Dimyati ${ }^{2}$ \\ Pendidikan Anak Usia Dini, Universitas Negeri Yogyakarta, Indonesia(1) \\ Pendidikan Ilmu Keolahragaan, Universitas Negeri Yogyakarta, Indonesia(2) \\ DOI: $10.31004 /$ obsesi.v6i1.926
}

\begin{abstract}
Abstrak
Tuntutan pembelajaran yang semakin kompleks menyebabkan semakin berkurangnya aktivitas yang berkaitan dengan nilai agama Islam pada anak usia dini. Sedangkan, pendidikan nilai agama Islam pada anak usia dini merupakan pondasi yang sangat penting sebagai peletakkan dasar keagamaan supaya menjadi pribadi yang taat beribadah. Penelitian ini bertujuan untuk menganalisis nilai agama Islam pada anak usia dini. Metode penelitian yang digunakan dalam penelitian ini adalah kajian pustaka dengan mengumpulkan data dari karya tulis ilmiah dan penelitian terdahulu. Hasil penelitian menunjukkan bahwa nilai agama Islam dapat ditanamkan melalui kegiatan pembiasaan dan keteladanan. Oleh karena itu sebagai seorang guru maupun orang tua harus berupaya memiliki kepribadian baik yang dapat dijadikan contoh sebagai sifat teladan bagi anak. Guru dan orangtua sebaiknya selalu meningkatkan wawasan pengetahuan, pemahaman dan keterampilan yang berkaitan dengan pengembangan nilai agama Islam anak usia dini.
\end{abstract}

Kata Kunci: nilai agama; islam; anak usia dini.

\begin{abstract}
Increasingly complex learning demands lead to reduced activities related to Islamic values in early childhood. Meanwhile, the education of Islamic religious values in early childhood is a very important foundation as a laying of the religious foundation so that they become devout individuals of worship. This study aims to analyze the value of Islam in early childhood. The research method used in this research is literature review by collecting data from scientific papers and previous research. The results showed that the value of the Islamic religion can be instilled through habituation and exemplary activities. Therefore, as a teacher and a parent, we must strive to have a good personality that can be used as an example as a role model for children. Teachers and parents should always improve their knowledge, understanding and skills related to the development of Islamic religious values in early childhood.
\end{abstract}

Keywords: religious values; Islam; early childhood.

Copyright (c) 2021 Bina Fitriah Ardiansari, Dimyati

$\triangle$ Corresponding author :

Email Address : binafitriah@gmail.com (Yogyakarta, Indonesia )

Received 28 November 2020, Accepted 31 December 2020, Published 02 June 2021 


\section{PENDAHULUAN}

Anak usia dini adalah seorang individu yang sedang mengalami pertumbuhan dan perkembangan. Pertumbuhan berkaitan dengan bagian tubuh yang dapat diukur misalnya berat badan, tinggi badan, lingkar kepada. Sedangkan perkembangan merupakan perubahanperubahan yang terjadi dalam hidupnya. Usia dini merupakan masa yang tepat untuk memberikan dasar pengembangan kemampuan fisik, bahasa, sosial emosional, konsep diri, seni moral dan nilai-nilai agama (Rizqina \& Suratman, 2020; Trisnawati et al., 2020). Oleh karena itu anak memiliki potensi besar untuk mengoptimalkan perkembangannya. Pertumbuhan dan perkembangan berjalan secara beriringan.Setiap aspek perkembangan anak harus dikembangkan secara optimal, karena antara aspek satu dan lainnya saling berkaitan dan mempengaruhi.

Pendidikan mencakup proses hidup dalam rangka mengembangkan potensi yang dimilikinya supaya dapat berjalan secara optimal. Pendidikan anak usia dini harus menjadi proses awal pertumbuhan dan perkembangan seseorang sebelum memasuki umur dewasa. Pendidikan anak usia dini merupakan pemberian upaya untuk membimbing, mengasuh, dan menstimulasi anak sehingga akan menghasilkan kemampuan dan keterampilan bagi anak. Selain itu, anak usia dini harus mempunyai hak untuk mendapatkan pendidikan, perawatan, pengasuhan, kesehatan serta kebutuhan gizinya. Tujuan pendidikan bagi taman kanak-kanak yaitu membantu meletakkan dasar untuk mengembangkan sikap, perilaku, pengakuan, keterampilan, dan kreativitas yang nantinya nantinya akan diperlukan anak untuk pertumbuhan dan perkembangannya (Wandi \& Mayar, 2019).

Salah satu bagian penting yang harus mendapatkan perhatian terkait dengan pendidikan anak usia dini yaitu pendidikan nilai agama Islam. Pendidikan nilai agama berkaitan dengan kemauan melaksanakan ajaran agama dalam kehidupan sehari-hari. Anak harus diberikan bimbingan dan arahan yang tepat dalam memahami tentang nilai keagamaan anak usia dini. Kegiatan keagamaan anak usia dini berkaitan dengan kegiatan berdoa, beribadah dan berperilaku sesuai ajaran agama. Manfaat kegiatan keagamaan yang dilakukan anak usia dini diharapkan anak kelak akan menjadi individu yang taat beribadan dan berperilaku sesuai ajaran agamnya. Apabila anak secara terus menerus dilatih dengan cara yang kurang tepat maka ketika mereka berusia dewasa tidak memiliki kepedulian yang tinggi pada kehidupan beragama dalam kesehariannya (Fitriyah, 2019; Saputra, 2014).

Pendidikan nilai keagamaan pada anak usia dini merupakan pondasi yang kokok dan sangat penting sehingga perlu ditanamkan sejak dini. Apabila nilai keagamaan tidak berikan sejak dini akan menghambat perkembangan nilai agama dan moral anak dalam keberlangsungan kehidupan selanjutnya. Pendidikan keagamaan merupakan awal yang baik bagi pendidikan anak untuk menjalani kehidupan selanjutnya. Pendidikan harus berprinsip pada pengembangan nilai agama sebagai upaya untuk melaksanakan ibadah dan berperilaku terpuji sesuai dengan ajuran agama.

Nilai agama untuk anak usia dini ditanamkan melalui keteladanan dan pembiasaan dari guru maupun orangtua. Jika orangtua dan guru membiasakan dan memberikan teladan yang baik untuk anak dengan melakukan kebaikan-kebaikan dan peribadahan yang baik maka kemungkinan besar akan berkembang menjadi individu yang berakhlak mulia. Keteladanan yang dilakukan oleh orangtua maupun guru mengharuskan untuk mempelajari, memahami dan mampu mengimplementasikan dan mengarahkan pada aspek perkembangan nilai agama untuk anak usia dini.

Menurut Hakim dalam agama Islam nilai agama mencakup aqidah, ibadah dan akhlak (Saputra, 2014). Penanaman nilai-nilai agama merupakan suatu upaya mengenalkan dan mengajarkan ajaran agama kepada agama kepada anak agar anak dapat mengetahui dan memahaminya dan kelak melaksanakan ajaran agama dengan baik (Saputra, 2014). Pendidikan nilai agama Islam sejak dini merupakan tanggungjawab bersama semua pihak, baik guru maupun orangtua. Bagi orang tua muslim, pandangan tentang nilai keagamaan 
Islam erat kaitannya dengan pengasuhannya (Isnaningsih \& Rohman, 2019). Tugas pengasuhan menurut Rahayu yaitu pemeliharaan fitrah Islamiyah anak (Imroatun et al., 2020).

Pendidikan nilai keislaman pada anak usia dini merupakan suatu hal yang sangat fundamental, karena dapat dijadikan sebagai pondasi bagi perkembangan anak pada masa berikutnya (Latuconsina et al., 2020). Penelitian menunjukkan bahwa nilai agama bertujuan untuk membentuk seseorang memiliki jiwa dan berkarakter Islami (Noor, 2017). Penanaman nilai agama Islam sejak usia dini supaya kelak anak dapat membedakan baik buruk, benar salah, sehingga anak dapat menerapkannya dalam kehidupan sehari-hari (Fadlyana \& Larasaty, 2016). Anak yang tumbuh dan berkembang dalam lingkungan yang baik akan menghasilkan karakter yang baik pula (Agustriana, 2018; Bahri \& Fitriani, 2019). Manfaat penelitian yang dilakukan berkaitan dengan nilai keislaman pada anak usia dini yaitu sebagai pedoman kegiatan untuk meletakkan dasar-dasar pendidikan agama Islam supaya anak menjadi pribadi yang taat beribadah dan berperilaku sesuai dengan ajaran agama Islam. Ada tiga tahapan perkembangan keagamaan pada anak yaitu the fairy tale stage, the realistic stage, the individual stage (Makhmudah, 2020). Pokok materi atau muatan materi pembelajaran nilai keagamaan anak bersifat aplikatif, enjoyable, dan mudah ditiru. Prinsip-prinsip pengembangan nilai keagamaan anak usia prasekolah yaitu Pendidik harus menciptakan hubungan baik dan akrab kepada anak, bersikap dan bersifat teladan, mengarahkan dan membimbing, memberikan motivasi yang membangun, dan dalam proses pembelajaran harus disesuaikan dengan kemampuan anak (Ananda, 2017; Bahri \& Fitriani, 2019). Metode dalam pengembangan nilai keagamaan Islam anak usia dini dapat ditempuh melalui metode bercerita, metode bernyanyi, metode karyawisata, metode bermain peran, metode bercakapcakap, metode demonstrasi, metode proyek, metode pemberian tugas, dan metode pembiasaan (Bahri \& Fitriani, 2019; Wilis \& Hartati, 2020). Strategi pengembangan nilai agama Islam pada anak usia dini dapat dilakukan melalui kegiatan rutinitas, kegiatan terintegrasi, dan kegiatan khusus (Bahri \& Fitriani, 2019; Iftitah, 2020). Penilaian yang dapat dilakukan oleh guru terhadap pengembangan nilai agama anak usia dini dapat dilakukan melalui pengamatan atau observasi, percakapan (tanya jawab), penugasan, unjuk kerja, penilaian hasil karya, pencatatan anekdot dan portofolio (Hartati \& Zulminiati, 2020; Revita \& Hartati, 2020; Sari \& Wisroni, 2020).

Penelitian terdahulu yang dilakukan oleh Wahyuningsih dan Suyanto, menyatakan bahwa orang tua berekspektasi terlalu tinggi terhadap anak sebagai generasi penerus bangsa. Beberapa orang tua juga menyekolahkan anaknya pada lembaga pendidikan yang berbasis Islami. Kurikulum Islam yang begitu padat terkadang membuat anak merasa lelah, karena anak merasa tertekan dengan adanya kurikulum agama Islam yang banyak. Akan tetapi, ada suatu permasalahan yang muncul yaitu setiap orang tua dan pendidik belum memahami strategi yang tepat dalam memberikan pendidikan beragama Islam kepada anak. Adanya masalah tersebut, beberapa orang tua mengalami kekecewaan, karena harapan tidak sesuai dengan kenyataan (Wahyuningsih \& Suyanto, 2015). Selain itu dalam penelitian yang dilakukan oleh Uyuni, menyayangkan orang tua dalam pengasuhan anak seringkali tidak diimbangi dengan ilmu pengetahuan terkait dengan mendidik anak yang dicontohkan Rasulullah SAW (Uyuni, 2019).

Bagi orang tua yang beragama Islam, pandangan tentang agama selalu berhubungan dengan pengasuhan. Pengasuhan berdasarkan agama ini menjadi tanggung jawab utama orangtua, dan menjadi tanggung jawab bersama dengan pendidik di lembaga pendidikan (Hadi, 2017). Dibutuhkan penanaman nilai agama yang kuat untuk bangsa ini supaya dapat memfilter pengaruh buruk bangsa lain (Fauziddin, 2016). Sehingga penanaman nilai tersebut sangat kuat, maka harus dilakukan sejak usia dini dengan memperhatikan tingkat kemampuan anak. Mengingat sangat pentingnya pembelajaran nilai agama Islam bagi anak usia dini beserta dengan strategi yang tepat bagi anak, saat ini orang tua beserta pendidik sangat serius untuk menambah ilmu terkait dengan nilai agama Islam bagi anak. Berdasarkan 
permasalahan yang ada, penelitian ini bertujuan untuk menjelaskan nilai agama Islam pada anak usia dini.

\section{METODOLOGI}

Penelitian ini menggunakan metode kepustakaan atau kajian pustaka. Metode penelitian ini bersumber dari berbagai kumpulan hasil karya ilmiah sebelumnya yang digunakan untuk menjawab berbagai permasalahan penelitian(Hasanah \& Sugito, 2020).Anderson (Pebriana, 2017) tujuan penelitian kajian pustaka yaitu untuk meringkas, menganalisis dan menafsirkan teori yang berhubungan dengan penelitian. Penelitian ini dimulai dengan melakukan pengumpulan data-data yang berasal dari berbagai karya tulis ilmiah yang relevan(Mukarromah et al., 2020).

Alasan melakukan penelitian kajian pustaka, yaitu: 1) permasalahan hanya dapat dijawab melalui penelitian kepustakaan; 2) kajian pustaka dibutuhkan sebagai salah satu tahap tersendiri, dimana studi pendahuluan diperlukan untuk memahami gejala baru yang sedang berkembang didalam masyarakat; 3) penelitian kepustakaan dapat di percaya hasilnya dalam menjawab permasalahan penelitian (Wandi \& Mayar, 2019). Berikut langkah-langkah yang dilakukan dalam penelitian kajian pustaka ini yaitu:

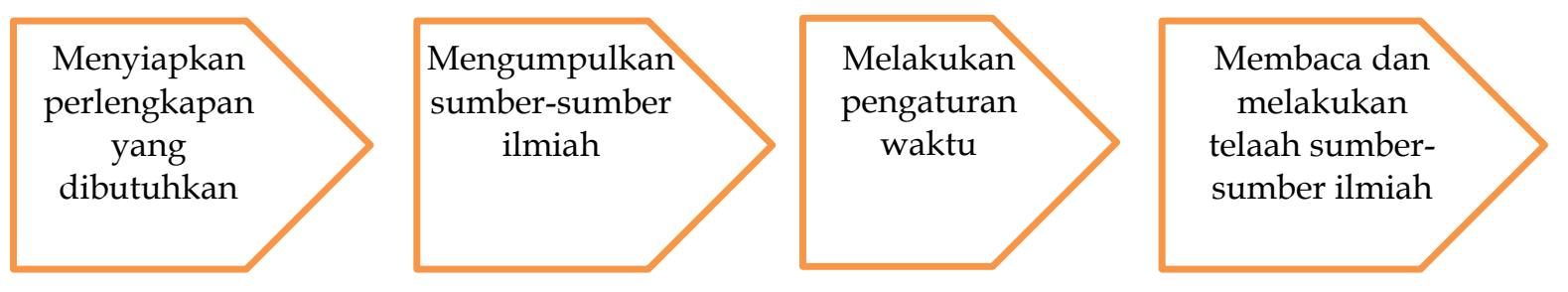

Gambar 1. Langkah-langkah penelitian kajian pustaka

Berdasarkan urutan diatas dapat dijelaskan bahwa terdapat empat langkah dalam melakukan kajian literatur yaitu; 1) menyiapkan perlengkapan yang dibutuhkan termasuk alat yang akan digunakan dalam melakukan penelitian; 2) mengumpulkan sumber-sumber ilmiah yaitu dengan mengumpukan berbagai sumber literatur dan karya ilmiah lainnya yang relevan; 3) peneliti melakukan pengaturan waktu dengan baik supaya tujuan penelitian dapat tercapai; 4) peneliti membaca dan melakukan telaah sumber pustaka tersebut secara mendalam untuk dijadikan sebagai landasan teori mengenai permasalahan yang diteliti (Ritonga \& Sutapa, 2020).

\section{HASIL DAN PEMBAHASAN}

Agama berkaitan dengan jalan yang wajib diikuti orang supaya sampai ke suatu tujuan suci serta mulia. Agama berasal dari "a" mempunyai makna tidak, dan "gama" mempunyai makna kacau (Ananda, 2017). Jadi agama diartikan sebagai; (a) jalan yang wajib dilaksanakan supaya sampai ke tujuan, (b) metode supaya sampai tujuan yang diridhai Tuhan, (c) tuntunan yang tidak membuat kacau manusia ataupun yang menertibkan hidup(Ananda, 2017).

Menurut Ansari (Ananda, 2017) agama mempunyai tiga unsur yaitu; (a) agama sebagai suatu sistem CREDO (tata keimanan atau tata keyakinan) atas sesuatu yang mutlak di luar diri manusia; (b) agama sebagai sistem RITUS (tata peribadatan) manusia kepada yang dianggapnya mutlak, (c) agama sebagai suatu sistem NORMA (tata kaidah) yang mengatur hubungan manusia dengan alam lainnya sesuai dan sejalan dengan tata keimanan dan tata peribadatan termaksud di atas. Unsur agama yang terakhir yaitu "akhlaq" (Ananda, 2017). Akhlaq merupakan manifestasi atau perwujudan iman terhadap Tuhan Yang Maha Esa. Unsur agama berkaitan dengan keyakinan atau kepercayaan, sesuatu yang harus dilakukan dan hukum perbuatan. Dalam Islam, ajaran tentang keyakinan disebut Iman dan ajaran yang wajib dilakukan disebut Islam. 
Penanaman keagamaan anak usia dini mengandung nilai pembersihan jiwa rohani, nilai moral serta nilai peningkatan taqwa kepada Allah(Makhmudah, 2020). Secara umum tujuan pengembangan nilai agama bagi anak yaitu memberikan dasar keimanan dengan pola takwa kepada Tuhan, akhlak yang baik, cakap, percaya pada diri sendiri, dan memiliki kesiapan untuk hidup bermasyarakat serta menjalankan kehidupan yang diridhai Tuhan Yang Maha Esa (Ananda, 2017). Tujuan khusus pengembangan nilai keagamaan anak prasekolah yaitu (Ananda, 2017), yaitu; (1) mengembangkan rasa iman dan cinta terhadap Tuhan; (2) membiasakan anak agar melakukan ibadah kepada Tuhan; (3) membiasakan perilaku yang didasari nilai agama; (4) membantu anak supaya memiliki kepribadian yang beriman dan bertakwa pada Tuhan.

Ada tiga tahapan perkembangan keagamaan pada anak (Makhmudah, 2020): 1) The Fairy Tale Stage. Ketika anak berusia 0-6 tahun anak berfikir bahwa Tuhan dan malaikat dianggap sebagai sosok besar raksasa dan bersayap atau anggapan lainnya. Hal ini berkaitan dengan dunia imajinasinya. 2) The Realistic Stage. Tahap ini dimulai pada usia 6-12 tahun, yang beranggapan bahwa agama bersifat konkrit. Malaikat dan nabi adalah suatu yang benar adanya seperti manusia yang bisa melihat dan mengawasi. 3) The Individual Stage. Tahap ini dimulai pada usia 13-18 tahun, yang terdiri dari tahap kolot, misted, dan simbol. Selain itu, individu mulai bisa berpikir kritis mengenai sesuatu yang kurang tepat. Individu dapat diajak berdiskusi dan berbicara dengan baik.

Standar Pencapaian nilai keagamaan anak prasekolah (Makhmudah, 2020): 1) Usia 2-3 tahun. Pengenalan agama dapat diajarkan melalui nyanyian lagu dan teput terkait agama yang diajarkan. Selain itu mulai mengenalkan doa-doa, sikap berdoa, mengenal sifat Tuhan, serta salam. 2) Usia 3-4 tahun. Anak mulai mengikuti bacaan dengan bernyanyi dan bertepuk tangan, menirukan gerakan beribadah, menghormati orangtua, guru dan orang di sekitarnya. 3) Usia 4-5 tahun. Anak mampu bernyanyi, bertepuk tangan, mulai menghafal doa pendek, berdoa untuk kegiatan, mulai menghafal doa dan gerakan ibadah, mengucap salam dan mengungkapkan terima kasih. 4) Usia 5-6 tahun. Anak mulai menguasai tahapan proses sebelumnya, anak lebih matang dalam menghafal doa dan melaksanakan aktivitas penanaman nilai-nilai agama anak usia dini.

Tahapan perkembangan nilai keagamaan pada AUD (Ananda, 2017; Bahri \& Fitriani, 2019; Makhmudah, 2020); 1) Unflective. Kemampuan pemahaman anak dalam mempelajari nilai keagamaan anak masih sebatas mengenalkan. Pemahaman mengenai keagamaan sehingga belum mendalam. Hal ini dapat dilihat pada saat kegiatan keagamaan yang masih bersikap dan bersifat kekanak-kanakan misalkan bercanda dan kegiatan main-main lainnya. 2) Egosentris. Egosetris memiliki arti bahwa individu lebih mementingkan dirinya sendiri dan tidak peduli dengan orang lain, individu lebih memfokuskan pada keuntungan dirinya sendiri. Sama halnya dengan sifat anak usia dini, anak masih sering berubah-ubah, anak belum mampu bersikap konsisten. Misalkan pada suatu waktu anak rajin dalam melaksanakan kegiatan keagamaan, tetapi pada suatu waktu anak bisa jadi menjadi malas untuk melakukan kegiatan keagamaan tersebut. Anak lebih memilih untuk bermain dengan temannya. Sifat ini masih wajar, sebagai orangtua dan pendidik memiliki kewajiban untuk mengarahkan dan membimbing terkait dengan nilai keagamaan anak. 3) Misunderstand. Tahap ini dilandasi dengan belum sempurnanya psikologis dan fisiologis yang menyebabkan banyak hal yang belum bisa ditangkap oleh anak, dan menyebabkan salah persepsi (misperception) ketika mereka belajar memahami makna dari sebuah ajaran atau pengetahuan agama yang masih bersifat abstrak bagia anak usia dini. Pada tahap ini anak akan membayangkan bahwa Tuhan itu siapa, Tuhan dimana, dan lain sebagainya. 4) Verbalis dan Ritualis. Tahap ini menjelaskan bahwa pemahaman anak tentang nilai keagamaan dimulai pada saat anak mengerti bahasa. Adanya kemampuan bahasa pada anak akan meningkatkan kemampuan komunikasi sehingga anak dapat menerima pembelajaran dari orang lain. Dengan demikian, pada tahap ini dalam agama Islam anak mulai dikenalkan dengan ritual keagamaan misalnya kegiatan shalat, hafalan doa, hafalan surat pendek, nama malaikat dan 
lainnya. Anak akan mempelajari hal tersebut melalui keteladanan, pengalaman, dan pembiasaan. 5) Imitatif. Pada tahap imitatif, anak bersifat imitasi atau meniru kegiatankegiatan ritual keagamaan. Misalnya dalam keagamaan Islam yaitu kegitana sholat, kegiatan berpuasa, kegiatan berwudhu, membaca iqro dan lain sebagainya. Dengan demikian lingkungan memberi pengaruh besar dalam pembelajaran keagamaan yaitu pemberian contoh pembiasaan yang baik untuk anak.

Pengembangan nilai keagamaan untuk anak usia prasekolah memiliki pokok materi. Pokok materi atau muatan materi pembelajaran nilai keagamaan anak bersifat (Ananda, 2017; Julianto, 2020; Riofita, 2016; Siswanta, 2017): 1) Aplikatif. Pembelajaran nilai keagamaan bersifat terapan yaitu kegiatan keagamaan berkaitan dengan kegiatan yang dilakukan secara rutin oleh anak dan dapat dilakukan oleh anak dalam kehidupan sehari-hari. 2) Enjoyable. Pemberian pembelajaran pada anak diupayakan dapat membuat anak merasa gembira sehingga anak dapat menikmati dan mengikuti dengan antusias dan tidak membosankan. 4) Mudah ditiru. Pemberian materi pembelajaran anak usia dini harus bisa dipraktekkan dan disesuaikan dengan kemampuan lahiriah anak.

Kegiatan pengembangan nilai keagamaan anak usia dini memiliki prinsip pembelajaran. Prinsip kegiatan nilai keagamaan bertujuan untuk mendukung kegiatan pembelajaran sehingga dapat menciptakan suasana pembelajaran yang baik bagi anak. Prinsip-prinsip pengembangan nilai keagamaan anak usia prasekolah yaitu (Ananda, 2017; Bahri \& Fitriani, 2019) pendidik harus; (a) menciptakan hubungan baik dan akrab kepada anak, sehingga anak tidak merasa takut; (b) bersikap dan bersifat teladan sehingga dapat dijadikan contoh bagi anak; (c) mengarahkan dan membimbing perilaku anak; (d) menggunakan komunikasi yang baik dan mudah diterima bagi anak; (e) memberikan motivasi yang membangun; (f) hendaklah bersifat bijak dalam berperilaku; (g) melaksanaan program pembelajaran pembentukan perilaku bersifat luwes/fleksibel disesuaikan dengan kemampuan anak.

Dalam rangka penyampaian materi pengembangan nilai keagamaan anak prasekolah pendidik harus memiliki prinsip yang baik. Hal ini bertujuan supaya materi dapat tersampaikan dengan baik. Prinsip yang harus dimiliki pendidik yaitu (Ananda, 2017); (1) kegiatan ditekankan pada aktivitas sehari-hari pada anak; (2) pemberian keteladanan dari lingkungan orangtua/sekolah; (3) prinsip developmentally appropriate practice (dap)/ pembelajaran yang tepat sesuai dengan perkembangan anak; (4) prinsip psikologi perkembangan anak usia dini; (5) pelaksanaan monitoring yang rutin supaya dapat mengetahui perkembangan dan kemajuan yang anak alam.

Penanaman nilai agama pada anak usia dini berkaitan dengan upaya pendidikan dan pengajaran nilai agama Islam yang dipahami dan dilakukan individu guna tercapainya tujuan pembelajaran agama islam yang diharapkan. Tujuan pembelajaram nilai agama Islam dapat tercapai apabila menggunakan metode yang tepat. Penggunaan metode pada pembelajaran nilai keagamaan hendaknya disesuaikan dengan sekolah, kemampuan guru, dan kemampuan anak dalam menerapkannya.

Metode dalam pengembangan nilai keagamaan Islam anak usia dini dapat ditempuh melalui (Bahri \& Fitriani, 2019; Wilis \& Hartati, 2020): 1) Metode bercerita. Metode bercerita dapat dijadikan media untuk menyampaikan pembelajaran anak usia dini, termasuk nilai keagamaan. Selain itu guru juga dapat menggunakan alat peraga untuk mendukung kegiatannya tersebut. Adanya media dan kegaitan yang menarik makan akan membuat suasana belajar menjadi lebih menarik dan menjadikan pengalaman yang unik bagi anak. Metode bercerita dapat dilihat pada saat kegiatan mendengarkan kisah para nabi yang diceritakan oleh guru atau dari televisi dan media elektronik lainnya. 2) Metode bernyanyi. Metode bernyayi pada anak usia dini biasanya berkaitan dengan tepuk dan nyanyian. Secara nyata kegiatan ini membuat anak bertambah senang, gembira dan lebih bersemangat. Melalui kegiatan bernyanyi dapat diselipkan makna pada syair lagu tersebut. Misalnya berkaitan dengan nyanyian rukun islam, rukun iman, dan keagamaan lainnya. 3) Metode karyawisata. 
Metode karyawisata merupakan pembelajaran mengamati secara langsung seperti mengamati makhluk hidup, benda-benda, dan bangunan. Pembelajaran ini sebelumnya tidak ditemukan anak di dalam kelas. Selain itu tujuan adanya metode karyawisata yaitu anak dapat mengobservasi dan mengalami sendiri dari dekat kegiatan tersebut. Misalnya kegiatan pengenalan tempat-tempat ibadah, tempat bersejarah keagamaan, dan kegiatan keagamaan lainnya. 4) Metode bermain peran. Metode bermain peran dalam kegiatan penanaman agama Islam yaitu untuk memerankan tokoh atau benda yang dapat diperagakan untuk mengembangkan imajinasi anak. Hal tersebut dapat dilihat pada saat pembelajaran nabi yaitu peragaan ketika belajar tentang gerakan sholat. Anak merasakan suasana beragama yang riil. 5) Metode bercakap-cakap. Metode ini berkaitan dengan komunikasi antara anak dan guru. Dengan metode ini anak dapat mengembangkan kemampuan mendengar, memahami dan kemampuan berbicara anak. Metode ini juga dapat membantu anak belajar menyimak pembelajaran yang telah disampaikan guru atau temannya. Selain itu, metode bercakapcakap, juga dapat mengembangkan kemampuan lainnya seperti kemampuan kognitif, bahasa sosial, konsep diri, dan pengembangan nilai keagamaan. 6) Metode demonstrasi. Metode ini anak menyaksikan peragaan langsung tentang hal-hal yang sulit dijelaskan dengan pendekatan biasa. Hal ini dapat terlihat pada saat guru menerangkan etika makan, sopan santun, etika berbicara, etika berpakaian, etika beribadan dan lain sebagainya. 7) Metode proyek. Metode proyek memberikan kesempatan pada anak untuk menggunakan lingkungan disekitar dan kegiatan sehari-harinya sebagai bahan pembahasan melalui serangkaian kegiatan. Dalam kegiatan keagamaan Islam metode proyek dapat digunakan pada saat peringatan hari keagamaan. Guru sebagai fasilitator memberikan bahan yang digunakan. Guru membimbing dan mengarahkan anak melakukan pembelajaran ini. 8) Metode pemberian tugas. Metode ini juga diartikan sebagai pekerjaan yang harus diselesaikan oleh anak. Tugas yang diberikan disesuaikandengan program pengembangan dan disesuaikan dengan kemampuan masing-masing anak. Guru dapat memberikan tugas baik secara individu maupun berkelompok. Misalkan guru dapat memberikan tugas memberikan tugas supaya anak dapat melafalkan doa sebelum makan secara berkelompok. 9) Metode pembiasaan. Metode pembiasaan merupakan cara belajar dengan memberikan suatu pembelajaran yang dilakukan secara terus menerus dalam jangka wkatu yang terukur atau dengan kata ain bahwa anak terbukti dapat terbiasa melakukan kegiatan tersebut (Ayuningrum, 2018).

Jenis media pendidikan yang dapat digunakan dalam pengembangan nilai agama Islam bagi anak usia dini yaitu media audio, media visual. Media audio visual (Hartati, 2020).Media audio merupakan media bentuk auditif (bisa didengar) yaitu telinga. Media visual merupakan media yang dapat dilihat oleh panca indera. Media audio visual yaitu kombinasi media antara audio dan visual yang disatukan menjadi satu yaitu dapat dilihat dan didengar oleh panca indera.

Pencapaian keberhasilan pengembangan nilai keagamaan Islam anak usia dini perlu didukung dengan unsur keteladanan maupun pembiasaan yang baik dari pendidik dan orangtua. Dalam pelaksanaannya perlu dilakukan secara bertahap dan harus memiliki strategi supaya mendapatkan hasil yang optimal. Strategi pengembangan nilai agama Islam anak usia dini dapat dilakukan melalui program pembiasaan atau rutinitas dalam kegiatan anak seharihari. Strategi tersebut mencakup program kegiatan rutin, program terintegrasi, dan program kegiatan khusus. Berikut penjelasan mengenai strategi pengembangan nilai agama Islam pada anak usia dini (Bahri \& Fitriani, 2019; Iftitah, 2020): 1) Kegiatan Rutinitas. Kegiatan rutin dalam pengembangan nilai agama anak usia dini berkaitan dengan kegiatan terpogram sehari-hari yang dilaksanakan secara berulang-ulang. Kegiatan tersebut meliputi pemberian salam, mengucapkan doa masuk kelas, berdoa sebelum dan sesudah makan, doa masuk dan keluar kamar mandi. Program kegiatan rutin ini dijadikan sebuah kebiasaan yang terpogram dan dijalankan secara konsisten dan terpadu dengan kegiatan belajar lainnya. 2) Kegiatan Terintegrasi. Kegiatan terintegrasi merupakan kegiatan yang tercantum jelas langkah serta 
kompetensi dasarnya dalam kegiatan harian yang disusun pendidik. Program kegiatan terintegrasi yang meliputi pengembangan atau pengayaan komponen materi nilai agama Islam yang disesuaikan dan dihubungkan dengan bidang pengembangan lainnya. 3) Kegiatan Khusus. Kegiatan khusus adalah program kegiatan yang membutuhkan waktu dan penanganan khusus. Kekhususan dalam program ini adalah pelaksanaan kegaiatan hanya dilakukan pada waktu tertentu, memerlukan pembahasan lebih mendalam, dan dukungan media pembelajaran yang memadai. Contoh kegiatan khusus yaitu praktik tayamum, pengenalan kegiatan ibadah haji, pengenalan zakat fitrah serta pengenalan ibadah Qurban.

Penilaian yang dapat dilakukan oleh guru terhadap pengembangan nilai agama anak usia dini dapat dilakukan melalui pengamatan atau observasi, percakapan (tanya jawab), penugasan, unjuk kerja, penilaian hasil karya, pencatatan anekdot dan portofolio (Hartati \& Zulminiati, 2020; Revita \& Hartati, 2020; Sari \& Wisroni, 2020). 1) Pengamatan atau observasi. Pengamatan atau observasi adalah kegiatan pengumpulan data penilaian dnegan cara melakukan pengamatan secara langsung terhadap perilaku dan sikan anak yang mengacu oada indikator yang telah ditetepkan sebelumnya. Observasi dapat dilakukan melalui alat bantu rekam seperti daftar ceklist, skala penilaian, catatan anekdot dan lainnya. 2) Percakapan (tanya jawab). Penilaian percakapan (tanya jawab) dilakukan melalui cerita antara anak dan guru maupun sebaliknya. Percakapan dilakukan sesuai dengan topik pembicaraan pada program tema yang dilaksankan pada saat itu. Ada dua macam penilaian dalam kegiatan ini yaitu percakapan yang terstruktur dan tidak terstruktur. 3) Penugasan. Penugasan yaitu kegiatan pemberian tugas yang akan dikerjakan oleh anak. Seperti kegiatan mewarnai gambar masjid, membuat banguan masjid menggunakan balok, meronce, menciptakan bentuk, dan kegiatan lainnya. 4) Unjuk kerja. Penilaian ini dilakukan berdasarkan hasil pengamatan terhadap aktivitas siswa. Kegiatan unjuk kerja dalam pengembangan nilai agama Islam anak usia dini dapat dilihat pada saat kegiatan sikap berdoa, bernanyi tentang keislaman, dan membaca iqra. 5) Penilaian hasil karya. Penilaian hasil karya merupakan penilaian hasil kerja siswa setelah melakukan kegiatan. Kegiatan tersebut dapat berupa pekerjaan karya seni, tampilan anak, keterampilan anak, dan lainnya. 6) Pencatatan anekdot. Pencatatan anekdot adalah kegiatan pencatatan yang didasarkan atas peristiwa-peristiwa penting terkait dengan sikap dan perilaku anak dalam situasi tertentu. Pencatatan anekdot dapat berupa suatu hal positif maupun hal negatif. 7) Portofolio. Portofolio adalah penilaian berkelanjutan yang didasarkan pada kumpulan informasi yang menunjukkan perkrmbangan kemampuan peserta didik dalam suatu periode tertentu. Data yang dapat dijadikan portofolio yaitu hasil lembar kerja anak, yang dapat berupa hasil mewarnai, hasil menggambar, hasil menulis dan lainnya.

Pengembangan nilai agama Islam bagi anak usia dini dapat dilaksanakan melalui pembiasaan sehari-hari seperti mengucapkan salam, membaca doa sehari-hari, membaca surat pendek, praktik wudhu dan azan, praktik salat berjamaah, praktik infaq untuk qurban, sifat jujur, hadits-hadits pendek, asma' ul husna, dan kegiatan hari besar keagamaan (Kholida, 2017; Siswanta, 2017; Wahab, 2018). Pelaksanaan kegiatan pengembangan nilai keagamaan dilakukan secara rutin. Pelaksanaan kegiatan ditinjau dan dicatat dalam buku laporan perkembangan anak dan akan disampaikan pada orangtua. Berikut kegiatan keislaman pada anak usia dini: 1) Kegiatan sholat. Sholat yaitu kewajiban utama untuk umat Islam di dunia ini dengan tujuan mengharapkan ridha Allah SWT (Mistiningsih \& Fahyuni, 2020; Yasyakur, 2016). Sholat mengandung arti do'a yang berarti sebuah ungkapan dari permohonan serta harapan yang diucapkan seseorang (Yasyakur, 2016). Metode pembelajaran sholat bagi anak usia dini yaitu dapat melalui metode pembiasaan, dan keteladanan (Hermawan, 2019). Pengenalan ibadah sejak anak-anak bertujuan untuk mempelajari hukum ibadah sejak memasuki masa pertumbuhan supaya kelak anak terbiasa dan terdidik menaati hukum Allah (Wilis \& Hartati, 2020). Rukun sholat berkaitan dengan hal pokok yang harus dilakukan dalam sholat (Yasyakur, 2016). Rukun dalam sholat yaitu; (1) niat, (2) berdiri bagi yang mampu, (3) takbiratul ihram, (4) membaca doa iftitah, (5) membaca surat al fatihah, (6) membaca 
surat/ayat al quran, (7) ruku' serta tuma' ninah, (8) i'tidal, (9) sujud, (10) bangkit dari sujud, (11) duduk diantara dua sujud, (12) sujud kedua, (13) duduk tasyahud atau tasyahud awal, (13) duduk tasyahud atau tasyahud awal, (14) tertib(Arsyad, 2017.; Ayuningrum, 2018.; Yasyakur, 2016). Syarat sholat merupakan hal yang wajib dikerjakan sebelum sholat agar sholatnya(Yasyakur, 2016). Syarat sah sholat yaitu (a) beragama Islam, (b) berakal dan baligh, (c) suci dari hadats besar dan kecil, (d) suci seluruh anggota badan, (e) pakaian dan tempat, (f) menutup aurat, (g) mengetahui masuknya waktu sholat, (h) menghadap kiblat (Afiyah et al., 2019; Yasyakur, 2016). 2) Hafalan surat pendek. Bacaan Surat-surat pendek yaitu surat pendek yang ada dalam Al-Qur'an juz 30 (Marlina, 2018). Surat-surat pendek mempunyai jumlah ayat yang lebih sedikit daripada surat dalam Al-Qur'an yang lainnya. Pengajaran surat-surat penek bagi anak anak usia dini yaitu surat Al Fatihah, surat An Naas, surat Al Falaq, surat Al Ikhlas, surat Al Lahab, surat An Nashr, Al Kafirun, surat Al kautsar, surat Al Ma'un, surat Al Quraisy, surat Al Fill, surat Al Humazah, Surat Al Ashr. Dan sampai AdDuha (Fauziddin, 2016; Marlina, 2018; Rahmawati \& Dwiyanti, 2018; Saputra, 2016). Dalam penelitian (Taja et al., 2019) mengungkapkan surat-surat pendek yang di hafalkan anak dibagi berdasarkan dua tingkatan yaitu TK Kelompok A dan T Kelompok B. Adapun surat pendek yang dihafalkan yaitu Al -Fatihah, An-Nas, Al-Falaq, Al-Ikhlas, Al-Lahab, An-Nasr, AlKafirun, Al-Kautsar, Al-Maun, Al-Asr, Al-Quraish, Al-Fiil, Al-Humazah, At-Takatsur, AlQari'ah, Al-Adiyat, Al-Zalzalah, Al-Qadr,Ad-Dhuha, dan Al-Insyiroh. Indikator pencapaian hafal surat pendek yaitu hafal 7 surat pendek untuk kelompok A dan 11 surat pendek untuk kelompok B (Taja et al., 2019). Hafalan surat pendek pada setiap sekolah memiliki indikator pencapaiannya yang berbeda sesuai dengan sekolah masing-masing.

Hidayah dan Ulva (Maarif et al., 2020) berpendapat bahwa metode dalam menerapkan kegiatan menghafal ayat al-Quran dapat dilakukan melalui metode berikut: 1) Metode talqin. Metode talqin yaitu menghafal dengan cara membacakan dahulu ayat yang akan dihafal dan dilakukan secara berulang sampai anak menguasainya. Setelah anak mulai menghafal, maka dapat dilanjutkan pada ayat berikutnya. 2) Metode talqin dan mendengarkan. Metode talqin disini hampir sama dengan metode pertama, yang membedakan talwin disini dilakukan hanya sekali. Kemudian memperdengarkan ayat-ayat yang dihafal melalui rekamaan bacaan ayat tersebut. Selanjutnya rekaman ini diputar secara berulang sehingga anak dapat menghafal ayat tersebut. 3) Metode gerakan dan isyarat. Metode ini sangat dianjurkan bagi anak yang memiliki daya konsentrasi pendek dan tidak bisa fokus dalam satu kegiatan saja. Misalnya dalam kegiatanmenghafal ayat"wa aqiimush shalata, guru melakukan takbir sebagai isyarat shalat.Tantangan dari metode ini adalah guru harus memahami dengan benar makna ayat yang dihafalkan. 4) Metode membaca ayat yang akan dihafalkan. Metode ini dilakukan dengan cara menglafalkan sendiri ayat tersebut secara berulang-ulang. Setelah melafalkan secara berulang, secara tidak langsung anak dapat menghafalkan surat tersebut. 5) Metode hafalan dengan rekaman guru, anak, atau teman sebayanya. Media ini menggunakan alat untuk merekam dan membutuhkan partisipasi guru, orangtua, maupun teman sebaya. Langkah pertama mempersiapkan alat perekam lalu orangtua membacakan ayat yang akan dihafal. Selanjutnya orang tua meminta anak melakukan hal tersebut lalu mendengarkan hasil rekaman guru, anak, atau teman sebayanya secara berulang. 6) Hafalan doa sehari-hari. Membaca doa adalah kegiatan dari bentuk pendidikan. Berdoa adalah kegiatan memohon dan meminta sepenuh hati kepada Tuhan Yang Maha Esa. Berdoa merupakan kewajiban setiap individu sehingga perlu ditanamkan sejak usia dini(Muntaz et al., 2016). Doa yang dipelajari dalam usia prasekolah yaitu doa sebelum dan sesudah makan, doa sebelum dan sesudah belajar, doa untuk kedua orangtua, doa kedua orangtua, doa masuk dan keluar kamar mandi, doa masuk dan keluar masjid, doa perjalanan dan lainnya (Denico, 2018; Farida, 2017).

Pengembangan nilai agama Islam juga dapat diajarkan melalui hadis-hadis yang diajarkan disekolah yaitu hadis senyum, hadis kasih saying, hadis jangan marah, hadis kebersihan, hadis saling member hadiah,hadis sholat tiang agama, hadis Allah itu suka 
indah,hadis sabar dan pemaaf,hadis surga, hadis malu,hadis niat, hadis nasehat, hadis muslim adalah saudara,hadis perkataan baik, hadis keutamaan membaca al-quran, hadis puasa,hadis orang yang paling mulia,hadis larangan makan minum sambil berdiri, hadis tebar salam, hadis mencintai saudara, hadis manusia terbaik, hadis kewajiban menuntut ilmu, hadis keutamaan belajar, hadis keutamaan jujur, hadis member lebih baik daripada meminta(Nasution \& Fathurrahman, 2020; Sa' adah \& Muqowim, 2020).

Hadis yang dapat dipelajari dalam pembelajaran nilai agama pada anak usia dini yang dikutip dari Nurhayati (Sa'adah \& Muqowim, 2020) pada tabel 1.

Tabel 1. Hadis yang dapat dipelajari dalam pembelajaran nilai agama pada anak usia dini

\begin{tabular}{ll}
\hline \multicolumn{1}{c}{ Topik hadis } & \multicolumn{1}{c}{ Makna hadis } \\
\hline Hadis menuntut ilmu & menuntut ilmu itu wajib bagi setiap muslim \\
Hadis kasih sayang & $\begin{array}{l}\text { siapa tak sayang tidak akan disayang } \\
\text { kebersihan itu sebagian dari iman }\end{array}$ \\
Hadis kebersihan & muslim itu saudara muslim lainnya \\
Hadis bersaudara & senyumanmu dihadapan saudaramu adalah shodaqoh \\
Hadis tersenyum & tangan diatas lebih baik daripada tangan dibawah \\
Hadis suka memberi & tidak marah bagimu surga \\
Hadis larangan marah & jika kamu marah hendaknya diam \\
Hadis menahan marah & janganlah kamu makan dan minum sambil berdiri \\
Hadis adab makan & saling memberi hadiah maka kamu saling menyayangi \\
Hadis memberi hadiah & tidak masuk surga, yang suka mencela \\
Hadis tidak mencela & iman yang utama adalah sabar dan pemaaf \\
Hadis bersabar & sesungguhnya perbuatan itu tergantung dari niat \\
Hadis niat & sebaik-baik kamu adalah yang belajar al qur'an dan mengajarkannya \\
Hadis belajar al-qur'an & siapa yang menolong saudaranya yang sedang dalam kesulitan, maka \\
Hadts suka menolong & alloh akan menolongnya di dunia dan akhirat \\
& berkata yang baik adalah sedekah \\
Hadis menjaga lisan & ucap salam sebelum bicara \\
Hadis tentang salam &
\end{tabular}

Disamping menghafalkan hadis, pengembangan bilai agama juga dikembangkan dengan mempelajari wudlu. Wudhu merupakan kegiatan wajib yang dijadikan sebagai salah satu syarat sah ibadah (Afiyah et al., 2019, 2019; Fadli, 2019). Wudhu sebagai kegiatan membersihkan tubuh dengan air yang dijadikan sebagai syarat dan rukunnya menghilangkan hadas kecil (Revita \& Hartati, 2020; Sucipto, 2017). Ada dua aspek kebersihan yaitu kebersihan lahir yang berupa mencuci bagian dari tubuh manusia, serta kebersihan batin berupa membersihkan kesalahan dan dosa yang dilakukan oleh anggota tubuh(Sucipto, 2017). Pembelajaran agama islam bagi anak usia dini yang cukup sering diajarkan pada anak yaitu pembiasaan wudhu yang disesuaikan dengan ajaran Al-Qur'an dan Sunnah dalam kehidupan sehari-hari (Revita \& Hartati, 2020). Kegiatan menanamkan kegiatan berwudhu pada anak usia dini akan lebih efektif melalui kegiatan pembiasaan, keteladanan dan metode demonstrasi dari guru dan orang tua(Akmal, 2018).

Tata cara berwudhu bagi anak usia dini yaitu; (1) niat wudhu, (2) berkumur, (3) membersihkan kedua lubang hidung, (4) membasuh muka, (5) membasuh kedua telapak tangan hingga lengan, (6) membasuh sebagian kepala, (7) mengusap kedua telinga, (8) membasuh kedua kaki hingga mata kaki, (9) tertib. Semua yang dibasuh diulang tiga kali, mendahulukan anggota badan yang kanan, dan berdoa setelah wudhu (Afiyah et al., 2019; Sucipto, 2017). Syarat sahnya wudhu yaitu; (1) beragama Islam, (2) Tamyiz, (3) bersih dari hadas besar dan kecil, (4) tidak ada sesuatu yang mencegah masukan air ke kulit, (5) menggunakan air suci dan menyucikan (Sucipto, 2017).

Selanjutnya Infaq, Sedekah, dan Zakat. Infaq merupakan bagian dari sedekah. Pengertian sedekah cakupannya lebih luas dari sekedar material, misalnya saja senyum. Sedangkan sedekah merupakan kegiatan memberikan harta kepada masyarakat fakir miskin, 
masyarakat yang membutuhkan, maupun pihak lain yang berhak mendapatkan sedekah tanpa disertai imbalan, tidak ada paksaan, waktu kapan saja dan berapa saja jumlahnya (Slamet et al., 2015). Bersedekah paling ringan bagi anak usia dini yaitu tersenyum, berbicara dengan baik, memberikan salam, meminjamkan barang atau sesuatu kepada orang lain(Astuti \& Aziz, 2019). Selain itu kegiatan bersedekah bisa dilakukan anak melalui kegiatan berbagi, tolong menolong, kegiatan infaq mingguan, kerja bakti, menjenguk ketika ada teman yang sedang sakit ataupun sedang terkena musibah (Astuti \& Aziz, 2019; Nofiaturrahmah, 2017). Zakat merupakan hukuma wajib bagi seorang muslim yang sduah memenuhi syaratnya (Parisi, 2017). Kegiatan berzakat merupakan bagian dari salah satu kegiatan yang dapat membangun perekonomian masyarakat, zakat bukan hanya dijadikan sebagai ritual agama, akan tetapi dapat mencakup kegiatan bersosial, ekonomi, keadilan, dan kesejahteraan masyarakat (Sumarno, 2014). Kegiatan infaq, sedekah dan zakat merupakan kegiatan yang berkaitan dengan pengentasan kemiskinan dan kemaslahatan umat karenaberkaitan dengan peningkatan dan penumbuhan perekonomian masyarakat (Slamet et al., 2015).

\section{SIMPULAN}

Pendidikan nilai agama Islam bagi anak usia dini merupakan upaya untuk membimbing, mengasuh, dan menstimulasi anak agar anak memiliki sikap dan sifat keislaman sejak dini. Tujuan pendidikan agama Islam sejak dini untuk meletakkan dasar pendidikan agama Islam supaya menjadi pribadi yang taat beribadah dan berperilaku sesuai anjuran agama Islam. Penanaman keislaman anak dapat dilakukan melalui pembiasaan dan keteladanan yang dilakukan secara terus menerus. Sehingga guru dan orang tua harus selalu berupaya memberikan pembiasaan dan keteladanan yang baik untuk anak. Keberhasilan penanaman keislaman pada anak usia dini di sekolah dipengaruhi banyak hal diantaranya prinsip kegiatan, metode kegiatan, dan strategi pembelajaran agama islam pada anak usia dini. Penilaian nilai agama Islam pada anak usia dini dapat dilakukan melalui penilaian pengamatan atau observasi, percakapan (tanya jawab), penugasan, unjuk kerja, penilaian hasil karya, pencatatan anekdot serta portofolio.

\section{UCAPAN TERIMAKASIH}

Penulis mengucapkan terima kasih kepada semua pihak yang telah membantu dalam proses pembuatan artikel jurnal ini, semoga mendapatkan balasan dari Allah SWT. Aamiin.

\section{DAFTAR PUSTAKA}

Afiyah, A., Pratama, M. M., \& Nurhasanah, R. (2019). Evaluasi Pengenalan Tata Cara Berwudhu Dalam Pengembangan Pendidikan Agama Islam Melalui Media Gambar Pada Kelompok B Di Ra Asiah Kota Pekanbaru. Generasi Emas, 2(1), 71. https:// doi.org/10.25299/ge.2019.vol2(1).3303

Agustriana, N. (2018). Pengaruh Metode Edutainment Dan Identitas Diri Terhadap Keterampilan Sosial Anak. Al-Fitrah: Jornal of Early Childhood Islamic Education, 15. https:// doi.org/10.29300/alfitrah.v2i1.1517

Akmal, A. (2018). Penerapan Metode Demonstrasi Dalam Menigkatkan Kemampuan Berwudhu Pada Kelompok B3 Tk Islam YLPI Marpoyan. Generasi Emas, 1(1), 62. https://doi.org/10.25299/ge.2018.vol1(1).2257

Ananda, R. (2017). Implementasi Nilai-nilai Moral dan Agama pada Anak Usia Dini. Jurnal Obsesi : Jurnal Pendidikan Anak Usia Dini, 1(1), 19. https:// doi.org/10.31004/obsesi.v1i1.28

Arsyad, J. (2017). Meningkatkan Keterampilan Sholat Fardhu Dan Baca Al-Qur'an Melalui Metode Tutor Sebaya di SMPN 4 Lima Puluh Kabupaten Batu Bara. Jurnal An Sira: Pengembangan Profesi Guru Pendidikan Islam. http://dx.doi.org/10.30821/ansiru.v1i1.984 
DOI: 10.31004/obsesi.v6i1.926

Astuti, R., \& Aziz, T. (2019). Integrasi Pengembangan Kreativitas Anak Usia Dini di TK Kanisius Sorowajan Yogyakarta. Jurnal Obsesi : Jurnal Pendidikan Anak Usia Dini, 3(2), 294. https:// doi.org/10.31004/obsesi.v3i2.99

Ayuningrum, D. (2018). Peningkatan Kemampuan Hafalan Bacaan Sholat Anak Usia 6 Tahun Melalui Metode Pembiasaan. Jurnal Pendidikan Islam, 15. https://doi.org/10.37542/iq.v1i02.13

Bahri, H., \& Fitriani. (2019). Edutaiment Dalam Perkembangan Nilai Nilai Moral Dan Agama Anak. At-Ta'lim: Media Informasi Pendidikan Islam. https://doi.org/10.29300/attalim.v18i1.1951

Denico, A. (2018). Pengelolaan Pembelajaran Pendidikan Anak Usia Dini Di Kb Cerdas Kecamatan Batu Hampar Kabupaten Rokan Hilir. Generasi Emas: Jurnal Pendidikan Islam Anak Usia Dini, 01(02), 18. https:// doi.org/10.25299/ge.2018.vol1(2).2564

Fadli, F. (2019). Metode Praktik Dalam Memperkenalkan Nilai-Nilai Keagamaan Pada Anak Usia Dini Di Paud Mawar Tasikrejo Pemalang. ThufuLA: Jurnal Inovasi Pendidikan Guru Raudhatul Athfal, 7(1), 16. https://doi.org/10.21043/thufula.v7i1.4938

Fadlyana, E., \& Larasaty, S. (2016). Pernikahan Usia Dini dan Permasalahannya. Sari Pediatri, 11(2), 5. https://doi.org/10.14238/sp11.2.2009.136-41

Farida, S. (2017). Pengelolaan Pembelajaran PAUD. Wacana Didaktika: Jurnal Pemikiran $\begin{array}{llll}\text { Penelitian Pendidikan dan } & \end{array}$ https://doi.org/10.31102/wacanadidaktika.5.02.189-200

Fauziddin, M. (2016). Pembelajaran Agama Islam Melalui Bermain Pada Anak Usia Dini. Jurnal Obsesi: Jurnal Pendidikan Anak Usia Dini, 10. ttps://doi.org/10.31004/obsesi.v2i2.37

Fitriyah, F. (2019). Implementasi Pengembangan Nilai Moral Dan Agama Pada Anak Usia Dini Melalui Metode Keteladanan Di Tk Al-Muhsin. Islamic EduKids, 1(1), 1-7. https://doi.org/10.20414/iek.v1i1.1809

Hadi, S. (2017). Pola Pengasuhan Islami Dalam Pendidikan Keluarga (Penguatan Peran Keluarga Jamaah Masjid Baitul Abror Teja Timur). TADRIS: Jurnal Pendidikan Islam, 12(1), 117. https:// doi.org/10.19105/tjpi.v12i1.1290

Hartati, S. (2020). Studi Literatur: Instrument Evaluasi yang digunakan dalam Pembelajaran Moral dan Agama Anak Usia Dini. Jurnal Pendidikan Tambusai, 4, 13. https://doi.org/10.31004/jptam.v4i2.569

Hartati, S., \& Zulminiati, Z. (2020). Fakta-Fakta Penerapan Penilaian Otentik di Taman KanakKanak Negeri 2 Padang. Jurnal Obsesi : Jurnal Pendidikan Anak Usia Dini, 5(2), 10351044. https:// doi.org/10.31004/obsesi.v5i2.521

Hasanah, N., \& Sugito. (2020). Analisis Pola Asuh Orang Tua terhadap Keterlambatan Bicara pada Anak Usia Dini. Jurnal Obsesi: Jurnal Pendidikan Anak Usia Dini, 10. https://doi.org/10.31004/obsesi.v4i2.456

Hermawan, R. (2019). Pengajaran Sholat Pada Anak Usia Dini Perspektif Hadis Nabi Muhammad SAW. INSANIA : Jurnal Pemikiran Alternatif Kependidikan, 23(2), 282291. https:// doi.org/10.24090/insania.v23i2.2301

Iftitah, S. L. (2020). Strategi Pengembangan Nilai-Nilai Keagamaan pada Anak Usia Dini di TK Islamic Center Surabaya. Kindergarten: Journal of Islamic Early Childhood Education, 3(1), 23. https://doi.org/10.24014/kjiece.v3i1.9407

Imroatun, Nirnala, I., Juhri, \& Muqdamien, B. (2020). Kajian Literatur Pengasuhan Anak Usia Dini Dalam Islam. As-Sibyan: Jurnal Pendidikan Anak Usia Dini.

Isnaningsih, A., \& Rohman, A. (2019). Participation of Mothers Who Work in Religious Activities Towards Child Behavior. Jurnal Obsesi : Jurnal Pendidikan Anak Usia Dini, 3(1), 199. https://doi.org/10.31004/obsesi.v3i1.157

Julianto, T. A. (2020). Metode Menghafal dan Memahami al-Qur'an bagi anak usia dini melalui Gerakan Isyarat ACQ. Iqro: Journal of Islamic Education, 14. https://doi.org/10.24256/iqro.v3i1.1439 
Kholida, L. (2017). Konfirmasi Nilai-Nilai Karakter Pada Anak Usia Dini. Al-Ta'dib: Jurnal Kajian Ilmu Kependidikan, 10(1), 18. http:/ / dx.doi.org/10.31332/atdb.v10i1.549

Latuconsina, H., Nazilatul Ula, N. S., Choirunnisa, S. M., Kurniawati, F. M., Nuresa, R., Zuhri, A. S., Umbu Nay, S. I., Arifin, S., Rumkel, R. H., Masykuri, A. A., \& Muzayid, A. (2020). Peningkatan Ibadah dan Amaliah Sosial Berbasis Masjid. Jurnal Pembelajaran Pemberdayaan Masyarakat (JP2M), 1(2), 59. https:// doi.org/10.33474/jp2m.v1i2.6548 Maarif, V., Nur, H. M., \& Chandrayoga, F. (2020). Game Edukasi Hafalan Surat Pendek AlQur'an The Adventure Of Ali. IJSE: Indonesian Journal Software Engineering, 1, 9. https://doi.org/10.31294/ijse.v6i1.8059

Makhmudah, S. (2020). Penanaman Nilai Keagamaan Anak Melalui Metode Bercerita. J-PAI: Jurnal Pendidikan Agama Islam, 6(2). https://doi.org/10.18860/jpai.v6i2.9189

Marlina, M. (2018). Teori Behavior dalam Meningkatkan Motivasi Hafalan Surat Pendek AlQuran. Irsyad : Jurnal Bimbingan, Penyuluhan, Konseling, dan Psikoterapi Islam, 6(4), 407-426. https:// doi.org/10.15575/irsyad.v6i4.907

Mistiningsih, C., \& Fahyuni, E. F. (2020). Manajemen Islamic Culture Melalui Pembiasaan Sholat Dhuha Berjamaah dalam Meningkatkan Karakter Kedisiplinan Siswa. MANAZHIM, 2(2), 157-171. https:// doi.org/10.36088/manazhim.v2i2.856

Mukarromah, T. T., Hafidah, R., \& Nurjanah, N. E. (2020). Kultur Pengasuhan Keluarga terhadap Perkembangan Moral Anak Usia Dini. Jurnal Obsesi : Jurnal Pendidikan Anak Usia Dini, 9. https://doi.org/10.31004/obsesi.v5i1.550

Muntaz, A., Hariansyah, Y., \& Aryanto. (2016). Perancangan Buku Doa Untuk Anak-Anak. Besaung: Jurnal Seni Desain dan Budaya, 1, 9. http:/ / dx.doi.org/10.36982/jsdb.v1i1.41

Nasution, U., \& Fathurrahman. (2020). Relevansi Hadis Larangan Marah Terhadap Kognis Dan Memori. Al-Qalb: Jurnal Psikologi Islam, 8. https:// doi.org/10.15548/alqalb.v11i1.1221

Nofiaturrahmah, F. (2017). Pendidikan Karakter yang Menyenangkan (Studi di PAUD Shofa Azzahro). ThufuLA: Jurnal Inovasi Pendidikan Guru Raudhatul Athfal, 5(1), 181. https:// doi.org/10.21043/thufula.v5i1.2357

Noor, T. R. (2017). Upaya Guru Dalam Menanamkan Nilai Agama Di Kb Al Muslim Surabaya. Edusiana: Jurnal Manajemen Pendidikan Islam, 4(1), 12. https://doi.org/10.30957/edusiana.v4i1.7

Parisi, S. A. (2017). Tingkat Efisiensi dan Produktivitas Lembaga Zakat di Indonesia. ESENSI, 7(1), 63-72. https://doi.org/10.15408/ess.v7i1.3687

Pebriana, P. H. (2017). Analisis Penggunaan Gadget terhadap Kemampuan Interaksi Sosial pada Anak Usia Dini. Jurnal Obsesi: Jurnal Pendidikan Anak Usia Dini, 11. https://doi.org/10.31004/obsesi.v1i1.26

Rahmawati, D., \& Dwiyanti, L. (2018). Meningkatkan Kemampuan Menghafal Surat-Surat Pendek Melalui Metode Kinestetik Anak Kelompok B TKIT Nurul Islam Pelem Kecamatan Pare Kabupaten Kediri Tahun Pelajaran 2016-2017. Seling: Jurnal Program Studi PGRA. https:// doi.org/10.29062/seling.v4i1.160

Revita, D., \& Hartati, S. (2020). Pelaksanaan Pembelajaran Ibadah Wudhu Di Taman KanakKanak Islam Terpadu Dar El-Iman 2 Kota Padang. Jurnal Ilmiah Pesona PAUD, 7(1), 26. https:// doi.org/10.24036/108650

Riofita, H. (2016). Bentuk Peranan Guru Dalam Memberikan Pendidikan Kepemimpinan. $\begin{array}{llll}\text { Potensia: Jurnal Kependidikan } & \text { Islam, }\end{array}$ https://doi.org/10.24014/potensia.v2i1.2533

Ritonga, R. A., \& Sutapa, P. (2020). Literasi dan Gender: Kesenjangan yang Terjadi di Tingkat Pendidikan Anak Usia Dini. Jurnal Obsesi: Jurnal Pendidikan Anak Usia Dini, 9. https:// doi.org/10.31004/obsesi.v5i1.749

Rizqina, A. L., \& Suratman, B. (2020). Peran Pendidik Dalam Menanamkan Nilai Agama Dan Moral Anak Usia Dini. Didakta: Jurnal Kependidikan, 14(1), 12. https:// doi.org/10.30863/didaktika.v14i1.760 
DOI: 10.31004/obsesi.v6i1.926

Sa'adah, N., \& Muqowim, M. (2020). Penyampaian Pesan Moral Hadis Pada Anak Usia Dini Melalui Metode Mendongeng Cas Cis Cus. Kiddo: Jurnal Pendidikan Islam Anak Usia Dini, 1(2), 147. https:/ / doi.org/10.19105/kiddo.v1i2.3495

Saputra, M. A. (2014). Penanaman Nilai-Nilai Agama Pada Anak Usia Dini Di R.A. Ddi Addariyah Kota Palopo. Al-Qalam: Jurnal Penelitian Agama dan Sosial Budaya, 14. https://doi.org/10.31969/alq.v20i2.190

Sari, N. Y., \& Wisroni, W. (2020). The Urgency of Parental Guidance for Youth Education in the Belajar Dari Rumah (BDR) Era. Spektrum: Jurnal Pendidikan Luar Sekolah (PLS), 8(3), 309. https:// doi.org/10.24036/spektrumpls.v8i3.109565

Siswanta, J. (2017). Pengembangan Karakter Kepribadian Anak Usia Dini (Studi Pada PAUD Islam Terpadu Di Kabupaten Magelang Tahun 2015). Inferensi, 11(1), 97. https://doi.org/10.18326/infsl3.v11i1.97-118

Slamet, S., Ernawati, J., Jurusan Arsitektur, Fakultas Teknik, Universitas Brawijaya, Nugroho, A. M., \& Jurusan Arsitektur, Fakultas Teknik, Universitas Brawijaya. (2015). Pemanfaatan Ruang Telaga Pada Tradisi Sedekah Bumi Desa Cerme Kidul, Kecamatan Cerme, Kabupaten Gresik. Review of Urbanism and Architectural Studies, 13(1), 47-55. https:// doi.org/10.21776/ub.ruas.2015.013.01.5

Sucipto, S. (2017). Peningkatan Pemahaman Cara Berwudhu melalui Penerapan Metode Demonstrasi dan Simulasi di Sekolah Dasar. Briliant: Jurnal Riset dan Konseptual, 2(1), 25. https:// doi.org/10.28926/briliant.v2i1.21

Sumarno, M. S. (2014). Perlakuan Akuntansi Zakat Pada Badan Amil Zakat (Studi Kasus Pada Badan Amil Zakat Kabupaten Sidoarjo). Jurnal Akuntansi Akunesa, 24.

Taja, N., Inten, D. N., \& Hakim, A. (2019). Upaya Meningkatkan Keterampilan Mengajar Baca Tulis Al-Qur'an bagi Guru. Jurnal Obsesi : Jurnal Pendidikan Anak Usia Dini, 3(1), 68. https://doi.org/10.31004/obsesi.v3i1.135

Trisnawati, Puastuti, D., \& Lutvia Soleha. (2020). Pemilihan Media Pembelajaran Terbaik Sebagai Sarana Pembelajaran yang Efektif Menggunakan Metode SAW. Jurnal Penelitian Ilmu Pendidikan, 13. https:// doi.org/10.21831/jpipfip.v13i1.30474

Uyuni, Y. R. (2019). Konsep Pola Asuh Orang Tua Dalam Perspektif Islam Terhadap Tumbuh Kembang Anak Dalam Keluarga. As-Sibyan: Jurnal Pendidikan Anak Usia Dini. https://doi.org/10.32678/as-sibyan.v4i1.1964

Wahab, W. (2018). Implementasi Pendidikan Agama Islam Pada Pendidikan Anak Usia Dini (PAUD). PUSAKA, 6(1), 79-92. https://doi.org/10.31969/pusaka.v6i1.39

Wahyuningsih, D., \& Suyanto, S. (2015). Implementasi Kearifan Lokal Melalui Model BCCT Untuk Pengembangan Kemampuan Sosial Anak Usia Dini. JPPM: Jurnal Pendidikan dan Pemberdayaan Masyarakat. https://doi.org/10.21831/jppm.v2i1.4840

Wandi, Z. N., \& Mayar, F. (2019). Analisis Kemampuan Motorik Halus dan Kreativitas pada Anak Usia Dini melalui Kegiatan Kolase. Jurnal Obsesi : Jurnal Pendidikan Anak Usia Dini, 8. https:// doi.org/10.31004/obsesi.v4i1.347

Wilis, A. N., \& Hartati, S. (2020). Kegiatan Ibadah Sholat Di Sentra Ibadah Pada Taman KanakKanak Khaira Ummah. Jurnal Pendidikan Tambusai, 4, 8. https://doi.org/10.31004/jptam.v4i1.497

Yasyakur, M. (2016). Penanaman Nilai Keislaman Pada Anak Dhuafa Di Paud Insan Cerdas Kota Bekasi. Early Childhood: Jurnal Pendidikan, 05, 46. https://doi.org/10.35568/earlychildhood.v4i1.804 